\title{
Plant growth, yield and fruit quality of 'Piemonte' tangor grafted onto 14 rootstocks on the northern coast of the state of Bahia, Brazil
}

\author{
Natiana de Oliveira França ${ }^{1}$, Eduardo Augusto Girardi ${ }^{2}$, Maurício da Silva Amorim ${ }^{1}$, \\ Abelmon da Silva Gesteira², Orlando Sampaio Passos ${ }^{2}$, Walter dos Santos Soares Filho ${ }^{2}$
}

\begin{abstract}
In the state of Bahia, Brazil, citrus production is mainly on the Northern Coast region, with major cultivation of 'Pera' sweet orange grafted onto 'Rangpur' lime. The production of mandarins and mandarin-like fruits is very low in spite of the increasing regional consumption. Varieties that are adapted to tropical sub humid conditions should be evaluated on different rootstocks for cultivation recommendation. This study assessed the performance of 'Piemonte' tangor over 14 rootstocks in Rio Real, BA. Planting was performed in 2006 on a cohesive yellow argisol, at $6.0 \mathrm{~m} \mathrm{x} 4.0 \mathrm{~m}$ spacing and with no irrigation. Plant growth, production, and physicochemical attributes of fruits in 2010-2014 were assessed, in addition to tree survival and drought tolerance based on leafroll. At nine years of age, rootstocks that induced greater cumulative production of 'Piemonte' were 'Riverside' and 'Indio' citrandarins, 'Santa Cruz Rangpur' lime, and 'Cleopatra', 'Sunki Tropical' and 'Sunki Maravilha' mandarins. Although four hybrid rootstocks were semidwarfing, their mean efficiency was equivalent to the other rootstocks $\left(\approx 5.5 \mathrm{~kg} \mathrm{~m}^{-3}\right)$, resulting in the lowest production. Drought tolerance and tree survival were similar among rootstocks with minimal loss, except for TSKFL x CTSW - 049 hybrid with only $33.33 \%$ of survival. 'Piemonte' tangor produced fruits with general good quality under the evaluated conditions, but only peel thickness and technological index (TI) were influenced by rootstocks, with the lowest TI averages recorded for fruits harvested from scions grafted onto TSKC x (LCR x TR) - 001 and 'Volkamer' lemon.
\end{abstract}

Index terms: Citrus spp., C. clementina $\mathrm{x}$ (C. reticulata $\mathrm{x}$ C. sinensis), Poncirus trifoliata, grafting, tree survival.

\section{Crescimento de planta, produção e qualidade de frutos de tangor 'Piemonte' sobre 14 porta-enxertos no litoral norte do Estado da Bahia}

\section{Corresponding author:}

Received: June 26, 2017. Accepted: November 13, 2017.

Copyright: All the contents of this journal, except where otherwise noted, is licensed under a Creative Commons Attribution License.
Resumo - Na Bahia, a produção de citros é concentrada no Litoral Norte, com cultivo predominante da laranjeira 'Pera' enxertada em limoeiro 'Cravo'. A produção de tangerinas é muito baixa, apesar do consumo regional crescente. Variedades adaptadas ao clima tropical subúmido devem ser avaliadas em combinação com diferentes porta-enxertos visando à recomendação de cultivo. Neste estudo, o desempenho do tangor 'Piemonte' foi avaliado sobre 14 porta-enxertos em Rio Real-BA. O experimento foi instalado a campo em 2006, em um Argissolo Amarelo coeso, no espaçamento 6,0 m x 4,0 m, sem irrigação. O crescimento de planta, a produção e os atributos físico-químicos de frutos foram avaliados em 2010-2014, além da sobrevivência de árvores e a tolerância à seca com base no enrolamento foliar. Aos nove anos de idade, os porta-enxertos que induziram maior produção acumulada foram os citrandarins 'Riverside' e 'Indio', o limoeiro 'Cravo Santa Cruz' e as tangerineiras 'Cleópatra', 'Sunki Tropical' e 'Sunki Maravilha'. Embora quatro porta-enxertos, híbridos tenham sido semiananizantes, sua eficiência foi semelhante à dos demais $\left(\approx 5,5 \mathrm{~kg} \mathrm{~m}^{-3}\right)$, resultando na menor produção. A tolerância à seca e a sobrevivência foram similares entre os porta-enxertos com perda mínima de plantas, à exceção de TSKFL x CTSW - 049, com apenas 33.33\% de plantas vivas. Em geral, o tangor 'Piemonte' produziu frutos com boa qualidade nas condições avaliadas, e apenas a espessura da casca e o índice tecnológico (IT) foram influenciados pelos porta-enxertos, com menores médias de IT sobre TSKC x (LCR x TR) - 001 e limoeiro 'Volkameriano'.

Termos para indexação: Citrus spp., C. clementina $\mathrm{x}$ (C. reticulata $\mathrm{x}$ C. sinensis), Poncirus trifoliata, enxertia, sobrevivência de árvores.

\footnotetext{
${ }^{1}$ Agronomist, Master of Science in Agrarian Sciences, Federal University of Recôncavo da Bahia, Cruz das Almas-BA. E-mails: natianafranca@ yahoo.com.br, m.s.amorim@hotmail.com. Master's work of the first author with CAPES scholarship.

${ }^{2}$ Agronomist, researcher at Embrapa Cassava \& Fruits, Cruz das Almas-BA. Emails: eduardo.girardi@embrapa.br, abelmon.gesteira@embrapa. br, orlando.passos@embrapa.br, walter.soares@embrapa.br
} 


\section{Introduction}

In 2015, mandarin production in Bahia was 12,1 tons in an area destined to harvest of 759 ha. São Paulo is the largest producer in Brazil, with 356,3 tons, followed by Minas Gerais, Paraná, Rio Grande do Sul, Rio de Janeiro, Espírito Santo, Goiás, Paraíba, and Bahia, the ninth national producer (IBGE, 2015). Bahia's production is well below the state's demand, which is why there is the possibility of local production, since varieties adapted to the Coastal Tablelands conditions are known and high quality fruits can be produced in the region.

In northeastern Brazil, mandarins and their hybrids are primarily grafted onto 'Rangpur' lime (Citrus limonia Osbeck), and their fruits do not have good quality for marketing on a large scale, because mandarin fruits are frequently greenish, tasteless and subject to granulation, as generally noted for mandarins cultivated in tropical climate (REUTHER, 1973; JOMORI et al., 2014). Therefore, new varieties of mandarins and mandarin-like fruits, preferably more adapted to the tropical sub humid climate, and alternative rootstocks are demanded in the region.

'Piemonte' tangor is a 'Clementine' mandarin hybrid ( $C$. clementina hort. ex Tanaka) with 'Murcott' tangor [unknown origin, probably a natural $C$. reticulata Blanco with sweet orange $C$. sinensis (L.) Osbeck hybrid], introduced from California, USA, with midseason to late fruit maturation, medium-sized fruits with globe to flat shape, similar to Murcott' tangor fruits, but with earlier maturation and more intense orange peel color in Northeastern Brazil (PASSOS et al., 2007; ALMEIDA; PASSOS, 2011). These characteristics, combined with resistance to transportation and high productivity, make this cultivar a real option to the citrus diversification in the region (MARTINS et al., 2015).

Rootstocks alternative to 'Rangpur' lime must present high drought tolerance and perform well in dry farming, condition prevalent in the citrus belt of northeastern Coastal Tablelands. This area is characterized by soils with low water retention and high subsurface density associated with periods of drought in the summer; these conditions result in severe water deficiency to plants that decreases yield (CINTRA, 2007). Good grafting compatibility is also a requirement, considering that 'Murcott' tangor is incompatible with trifoliate orange [Poncirus trifoliata (L.) Raf.] and some of its hybrids (POMPEU JUNIOR, 2005). In addition, information about the performance of 'Piemonte' tangor grafted onto different rootstocks is scarce (CARVALHO et al., 2016; MARTINS et al., 2015, 2016).

In this study, plant growth, yield and fruit quality of 'Piemonte' tangor were assessed on 14 rootstocks in dry farming on the northern coast of the state of Bahia.

\section{Material and Methods}

The experiment was installed on June 2006 at 6.0 $\mathrm{m} \times 4.0 \mathrm{~m}$ in the municipality of Rio Real, northern coast

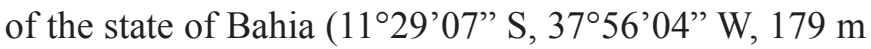
above sea level) and cultivation was dry farming. Climate, meteorological variables, soil, and cultural practices are exactly the same reported by França et al. (2016) evaluating a similar trial with 'Tuxpan Valencia' sweet orange in the same period and next to the experimental area.

'Piemonte' tangor was assessed on the following rootstocks: 'Sunki' [C. sunki (Hayata) hort. ex Tanaka] 'Tropical' and 'Maravilha' selections, 'Cleopatra' mandarin (C. reshni hort. ex Tanaka), 'Santa Cruz Rangpur' lime, 'Volkamer' lemon (C. volkameriana Ten. \& Pasq.), 'Indio' and 'Riverside' citrandarins (C. sunki $\mathrm{x}$ P. trifoliata 'English'), and experimental hybrids CLEO x CTCZ - 226, TSKFL x CTTR - 017, TSKC x CTSW - 028, TSKFL x CTSW - 049, TSKC x (LCR x TR) 001, TSKC x (LCR x TR) - 018 and LVK x LVA - 009. CLEO is the 'Cleopatra' mandarin, CTCZ is the 'Carrizo' citrange (C. sinensis $\mathrm{x} P$. trifoliata), TSKFL is the 'Florida Sunki' mandarin, CTTR is the 'Troyer' citrange, TSKC is the common 'Sunki' mandarin, CTSW is the 'Swingle' citrumelo ( $C$. paradisi Macfad. $\mathrm{x} P$. trifoliata), TR is the $P$. trifoliata, LCR is the 'Rangpur' lime, LVK is the 'Volkamer' lemon and LVA is the 'Valencia' sweet orange. All rootstocks were obtained from the Citrus Breeding Program of Embrapa Cassava and Fruits (CBP), Cruz das Almas-BA, except for citrandarins that were introduced from the United States Department of Agriculture (USDA), Indio Station - California, and selected by CBP, and the 'Volkamer' lemon and 'Cleopatra' mandarin, which are traditional citrus rootstocks.

Plant growth assessments were annually performed from 2010 to 2014, by measuring height $(\mathrm{H})$ and mean diameter (D) of canopy (mean of diameters in the row direction, and in the perpendicular row direction), and canopy volume $(\mathrm{V})\left(\mathrm{m}^{3}\right)$ estimated by $\mathrm{V}=2 / 3 \mathrm{x} \pi \mathrm{x} \mathrm{D}^{2} / 4 \mathrm{x}$ $\mathrm{H}$ (SILVA et al., 2013). Production per tree was measured from 2010 to 2014 . The average production efficiency in the period from 2010 to 2014 was also calculated by the average ratio between annual productions and canopy volumes in the respective years. Tree size results were presented only for 2014, at nine years of age.

Water deficiency tolerance was estimated during a severe drought period, which occurred on March 2013, using a scale of scores based on visual leafroll symptoms ranging from score 1 (absence of symptoms), score 2 (discreet withering up to half of the canopy), score 3 (discreet withering on whole canopy) and score 4 (intense withering along the entire canopy and with falling leaves), performed by four evaluators (Figure 1). Survival was calculated by the percentage of living trees until 2014. 
The physicochemical analysis of fruits included weight $(\mathrm{g})$, length $(\mathrm{cm})$, width $(\mathrm{cm})$, peel thickness $(\mathrm{mm})$, number of seeds per fruit, juice yield $(\%)$, titratable acidity (TA, \%), determined after titration with $0.1 \mathrm{~N}$ $\mathrm{NaOH}$, soluble solids (SS), using manual refractometer $\left({ }^{\circ}\right.$ Brix), maturity index calculated by the SS/TA ratio and technological index (TI, $\mathrm{kg} \mathrm{SS}$ box $^{-1} 40.8 \mathrm{~kg}$ ), calculated by applying the formula: $\mathrm{TI}=$ yield $\mathrm{x}$ SS $\mathrm{x} 40.8 / 100$ (SILVA et al., 2013). Quality variables were measured on January 2014, sampling ten fruits per plot, except for LVK x LVA - 009, which was not evaluated.

The experimental design was randomized blocks, with 14 treatments, three replicates and two plants in the plot. Results were submitted to analysis of variance and averages grouped by the Scott-Knott test $(P \leq 0.05)$, transforming data by $(\mathrm{x}+0.5)^{\wedge} 0.5$ whenever necessary in order to meet the normality and homogeneity of variance. Data on water deficiency tolerance were analyzed by the non-parametric test of Kruskal-Wallis $(P \leq 0.05)$.

\section{Results and discussion}

The assessed rootstocks resulted in differences in canopy size of 'Piemonte' tangor in 2014 (Table 1). Rootstocks were grouped into two categories according to the canopy size: diameter and volume. The highest diameters were obtained with 'Cleopatra', 'Sunki Maravilha' and 'Sunki Tropical' mandarins, 'Santa Cruz Rangpur' lime, 'Volkamer' lemon, 'Riverside' and 'Indio' citrandarins, and TSKC x CTSW - 028, TSKC x (LCR $x$ TR) - 018 and TSKC x (LCR x TR) - 001 (from 2.6 to $3.1 \mathrm{~m}$ ) hybrids, and the smaller diameters were found in CLEO x CTCZ - 226, TSKFL x CTTR - 017, TSKFL x CTSW - 049 and LVK x LVA - 009 (from 1.5 to $2.2 \mathrm{~m}$ ). The largest and the smallest canopy volumes followed the same groups, from 8.7 to $13.9 \mathrm{~m}^{3}$ and from 2.7 to $6.0 \mathrm{~m}^{3}$, respectively. On the other hand, plant height and production efficiency were similar among evaluated rootstocks, on average $2.3 \mathrm{~m}$ and $5.5 \mathrm{~kg} \mathrm{~m}^{-3}$, respectively (Table 1).

Table 1. Height (H), diameter (D), and canopy volume (V), production efficiency (E), tree survival (S) and drought tolerance score (T) of 'Piemonte' tangor [Citrus clementina hort. ex Tanaka x 'Murcott' tangor (C. reticulata Blanco x C. sinensis (L.) Osbeck)] grafted onto 14 rootstocks in rainfed cultivation in Rio Real-BA at nine years old.

\begin{tabular}{|c|c|c|c|c|c|c|c|c|c|c|c|c|}
\hline \multirow{2}{*}{ Rootstock $^{1}$} & $\mathrm{H}$ & & \multirow{2}{*}{\multicolumn{2}{|c|}{ D }} & \multirow{2}{*}{\multicolumn{2}{|c|}{$\begin{array}{l}\mathrm{V} \\
\mathrm{m}^{3}\end{array}$}} & \multicolumn{2}{|c|}{$\mathrm{E}^{2}$} & \multicolumn{2}{|l|}{$\mathrm{S}$} & \multicolumn{2}{|l|}{$\mathrm{T}^{3}$} \\
\hline & \multicolumn{2}{|c|}{-------- $m$--------- } & & & & & \multicolumn{2}{|c|}{$\mathrm{kg} \mathrm{m}^{-3}$} & \multicolumn{2}{|c|}{$\%$} & & \\
\hline 'Indio' citrandarin & 2.8 & $\mathrm{a}$ & 3.0 & $\mathrm{a}$ & 13.7 & $\mathrm{a}$ & 8.6 & $\mathrm{a}$ & 100 & $\mathrm{a}$ & 2.6 & $\mathrm{a}$ \\
\hline 'Riverside' citrandarin & 2.3 & $\mathrm{a}$ & 3.1 & $\mathrm{a}$ & 11.8 & $\mathrm{a}$ & 6.9 & $\mathrm{a}$ & 100 & $\mathrm{a}$ & 3.0 & $\mathrm{a}$ \\
\hline CLEO x CTCZ - 226 & 2.1 & $\mathrm{a}$ & 1.5 & $b$ & 2.7 & $\mathrm{~b}$ & 3.5 & a & 83.3 & $\mathrm{a}$ & 3.6 & $\mathrm{a}$ \\
\hline TSKFL x CTTR - 017 & 2.0 & $\mathrm{a}$ & 2.2 & $\mathrm{~b}$ & 5.4 & $\mathrm{~b}$ & 4.3 & $\mathrm{a}$ & 83.3 & $\mathrm{a}$ & 3.0 & $\mathrm{a}$ \\
\hline TSKC x CTSW - 028 & 2.4 & $\mathrm{a}$ & 2.9 & $\mathrm{a}$ & 11.1 & a & 5.7 & $\mathrm{a}$ & 100 & $\mathrm{a}$ & 2.7 & $\mathrm{a}$ \\
\hline TSKFL x CTSW - 049 & 1.6 & $\mathrm{a}$ & 1.5 & $b$ & 4.8 & $\mathrm{~b}$ & 6.3 & $\mathrm{a}$ & 33.3 & b & 2.3 & $\mathrm{a}$ \\
\hline TSKC x (LCR x TR) - 001 & 2.2 & $\mathrm{a}$ & 2.6 & a & 8.7 & $\mathrm{a}$ & 5.0 & a & 83.3 & $\mathrm{a}$ & 2.8 & a \\
\hline TSKC x (LCR x TR) - 018 & 2.3 & $\mathrm{a}$ & 2.7 & $\mathrm{a}$ & 9.0 & $\mathrm{a}$ & 6.5 & $\mathrm{a}$ & 100 & $\mathrm{a}$ & 2.5 & $\mathrm{a}$ \\
\hline LVK x LVA - 009 & 2.4 & $\mathrm{a}$ & 2.1 & $\mathrm{~b}$ & 6.0 & b & 3.3 & $\mathrm{a}$ & 100 & $\mathrm{a}$ & 3.3 & a \\
\hline 'Sunki Tropical' mandarin & 2.3 & a & 3.0 & $\mathrm{a}$ & 11.3 & a & 6.5 & $\mathrm{a}$ & 100 & $\mathrm{a}$ & 3.1 & a \\
\hline 'Sunki Maravilha' mandarin & 2.7 & $\mathrm{a}$ & 3.0 & a & 13.6 & $\mathrm{a}$ & 5.1 & $\mathrm{a}$ & 100 & $\mathrm{a}$ & 3.3 & a \\
\hline ‘Santa Cruz Rangpur’ lime & 2.7 & $\mathrm{a}$ & 3.1 & a & 13.9 & $\mathrm{a}$ & 5.8 & $\mathrm{a}$ & 100 & $\mathrm{a}$ & 2.3 & a \\
\hline 'Volkamer' lemon & 2.5 & $\mathrm{a}$ & 2.8 & $\mathrm{a}$ & 11.2 & $\mathrm{a}$ & 4.3 & $\mathrm{a}$ & 100 & $\mathrm{a}$ & 2.8 & $\mathrm{a}$ \\
\hline 'Cleopatra' mandarin & 2.6 & $\mathrm{a}$ & 3.1 & $\mathrm{a}$ & 13.2 & a & 6.0 & $\mathrm{a}$ & 100 & $\mathrm{a}$ & 3.0 & a \\
\hline $\mathrm{CV}(\%)$ & 18.3 & & 16.7 & & 21.7 & & 28.2 & & 17.7 & & 18.7 & \\
\hline
\end{tabular}

$(*)$ Averages followed by the same letter in column belong to the same group by the Scott-Knott test $(P \leq 0.05) .{ }^{1} \mathrm{CLEO}$ ('Cleopatra' mandarin), CTCZ ('Carrizo' citrange), TSKFL ('Sunki da Flórida' mandarin), CTTR ('Troyer' citrange), TSKC (Common 'Sunki’ mandarin), CTSW ('Swingle' citrumelo), TR (trifoliate orange), LCR ('Rangpur' lime), LVK ('Volkamer' lemon) and LVA ('Valencia' sweet orange). Respective scientific names are presented in Material and Methods. ${ }^{2}$ Average from 2010-2014. ${ }^{3}$ Visual score scale for drought symptoms ranging from score 1 (absence of symptoms), score 2 (discreet withering up to half of the canopy), score 3 (discreet withering in whole canopy) and score 4 (intense withering along the entire canopy and with falling leaves), evaluated at eight years old (March 2013). Averages followed by the same letter in column are equivalent by the non-parametric test of Kruskal-Wallis $(P \leq 0.05)$. 
TSKFL x CTSW - 049 hybrid rootstocks led to only $33.33 \%$ of tree survival nine years after planting, while loss of trees was minimal among the other rootstocks (Table 1). Similar results were reported for 'Tuxpan Valencia' sweet orange (FRANÇA et al., 2016), highlighting issues possibly related to graft incompatibility and poor plant growth with this hybrid in particularly. No blight symptoms were observed at nine years of age. It is also noteworthy that 'Piemonte' tangor had alternaria brown spot symptoms that resembled those of 'Murcott' tangor (PACHECO et al., 2012), even though its susceptibility was not investigated in this experiment. Drought tolerance was evaluated on March 2013 (accumulated deficit $>300$ $\mathrm{mm}$ ), but rootstocks did not differ based on a visual leafroll scale (Table 1: Figure 1).
In the cumulative production assessment for 'Piemonte' tangor during the period from 2010 to 2014 (five initial harvests), it was observed that 'Riverside' and 'Indio' citrandarins, 'Santa Cruz Rangpur' lime, and 'Cleopatra', 'Sunki Tropical' and 'Sunki Maravilha' mandarin rootstocks induced 190.6 to $108.7 \mathrm{~kg}_{\text {tree }}{ }^{-1}$, outperforming the other groups, resulting in less than 95.7 $\mathrm{kg}$ tree $^{-1}$ (Table 2). The rootstocks that have maintained good production in relation to the others, always being annually in the most productive groups, were 'Riverside' citrandarin and 'Sunki Tropical' mandarin, whereas 'Cleopatra' and 'Sunki Maravilha' mandarins induced later productions. Yield variations were observed throughout the years for all rootstocks, with expressive reductions in 2012 and 2013 as a result of the prolonged drought from late 2011 to 2013 (FRANÇA et al., 2016).

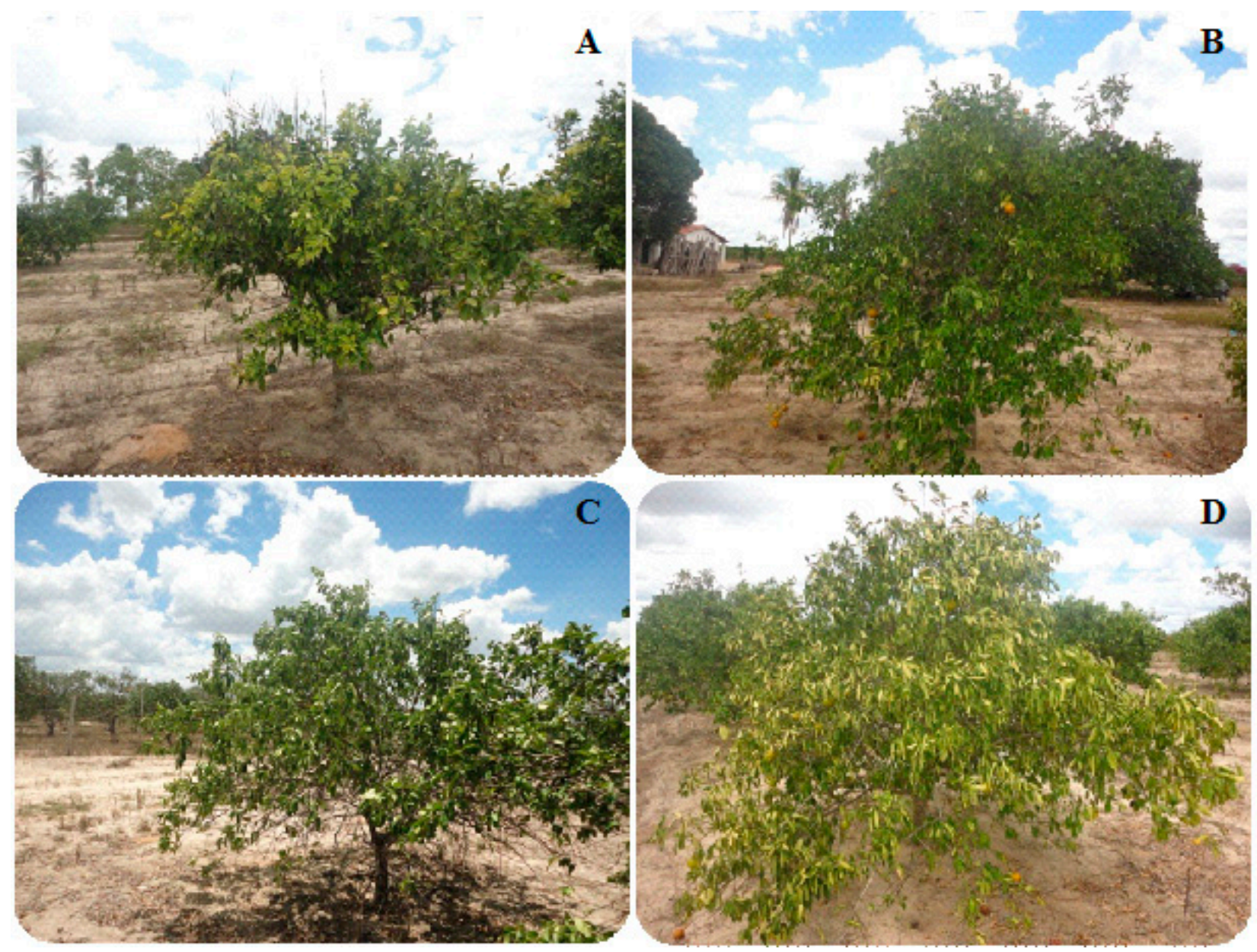

Figure 1. Visual score scale for drought symptoms ranging from score 1 (absence of symptoms) (A), score 2 (discreet withering up to half of the canopy) (B), score 3 (discreet withering in whole canopy) (C), and score 4 (intense withering along the entire canopy and with falling leaves) (D) of 'Piemonte' tangor [Citrus clementina hort. ex Tanaka x 'Murcott' tangor (C. reticulata Blanco x C. sinensis (L.) Osbeck)] grafted onto 14 rootstocks in rainfed cultivation in Rio Real-BA at eight years old. 
Harvest was conducted in different periods in each season, due to the alternating periods of drought and rain on the location (FRANÇA et al., 2016). In the year 2010, there was only one production in the month of July; in 2011, the highest production was in October, with another harvest in July; in 2012, there were four harvests, in January, June, August and November, being the major harvest in November; in 2013, there was only one harvest in March; finally, in 2014, there were two productions, one in January and other in June, with the largest production in January. Despite the irregular behavior regarding harvesting, an average cycle of $\approx 9$ months from blossom to harvest of 'Piemonte' tangor could be observed on the northern coast of Bahia.

Regarding fruit quality, rootstocks have not altered most of the assessed attributes (Table 3). Only peel thickness and technological index (TI) were influenced by rootstocks. 'Cleopatra', 'Sunki Tropical' and 'Sunki Maravilha' mandarins, 'Riverside' citrandarin and the hybrid TSKC x CTSW - 028 led to thinner fruit peel of 'Piemonte' tangor. The lowest TI averages were recorded for fruits of trees grafted onto TSKC x (LCR x TR) - 001 and 'Volkamer' lemon.

The differences in plant size observed for 'Piemonte' tangor on the evaluated rootstocks do not allow for high density orchards, since the four semi-dwarfing rootstocks (CLEO x CTCZ - 226, TSKFL x CTTR - 017, TSKFL $x$ CTSW - 049 and LVK x LVA - 009) did not compensate the lower production per tree with higher efficiency per canopy volume (Table 1). Although there was no difference regarding mean production efficiency, the evaluated rootstocks varied from 3.3 to $8.6 \mathrm{~kg} \mathrm{~m}^{-3}$ with the most vigorous varieties such as 'Riverside' citrandarin resulting in higher production per tree. Carvalho et al. (2016), evaluating 'Piemonte' tangor grafted onto 11 rootstocks on the Coastal Tablelands of Sergipe, Brazil, observed smaller trees and higher production efficiency on 'Swingle' citrumelo and on HTR - 051 trifoliate hybrid. The truly dwarfing rootstocks of 'Flying Dragon' trifoliate orange (P. trifoliata) and 'Troyer' and 'Carrizo' tetraploid citranges yielded from 8.9 to $12.1 \mathrm{~kg} \mathrm{~m}^{-3}$ of 'Span American' mandarin (C. reticulata) associated with $70 \%$ to $50 \%$ reduction in the canopy volume (SILVA et al., 2013).

The results described here corroborate previous reports on high yield and good performance of 'Piemonte' tangor grafted onto 'Rangpur' lime on the Coastal Tablelands of Northeastern Brazil (MARTINS et al., 2015, 2016). 'Santa Cruz Rangpur' lime and LVK x LCR - 010 led to higher drought tolerance of 'Piemonte' tangor in Umbaúba-SE, while the most sensitive rootstocks were 'Swingle' citrumelo, 'San Diego' citrandarin and 'Orlando' tangelo (C. paradisi x C. tangerina hort. ex Tanaka) (CARVALHO et al., 2016). The same authors reported higher cumulative yield for four harvests on 'Santa Cruz
Rangpur' lime and 'Red' rough lemon (C. jambhiri Lush.), with good averages on 'Riverside' citrandarin, 'Sunki Tropical' mandarin and LVK x LCR - 010.

'Sunki Maravilha' mandarin performed well as rootstock for 'Piemonte' tangor (Tables 1 to 3), but showed poor performance when grafted onto 'Tuxpan Valencia' sweet orange (FRANÇA et al., 2016). Therefore, its use should be further investigated as it is sensitive to drought and this may limit yield (SANTANA-VIEIRA et al., 2016). On the other hand, TSKC x CTSW - 028 induced higher production to 'Valencia' sweet orange in rain-fed cultivation in São Paulo, Brazil (RAMOS et al., 2015), which in turn was also not observed for 'Tuxpan Valencia' in Bahia (FRANÇA et al., 2016). TSKC x (LCR $\mathrm{x}$ TR) - 018 was also promising for 'Piemonte' tangor, as a result of intermediate production, and other hybrids from the same cross were also highlighted in previous work (RAMOS et al., 2015).

Fruit quality of 'Piemonte' tangor was not remarkably influenced by rootstocks, which corroborates previous works with this variety and other mandarin hybrids in Brazil (FIGUEIREDO et al., 2006; MOURÃO FILHO et al., 2007; ESPINOZA-NUÑEZ et al., 2007, 2008; LEDO et al., 2008; STUCHI et al., 2008; CARVALHO et al., 2016; MARTINS et al., 2015, 2016). In this work, mean fruit traits were: $220 \mathrm{~g}$ of weight; 6.42 $\mathrm{cm} \times 7.70 \mathrm{~cm}$ of fruit size (length $\mathrm{x}$ width, given a relation of 0.83 , which indicates flat fruits similar to those of 'Murcott' tangor); peel thickness of $2.0 \mathrm{~mm}$; $48 \%$ of juice content with 16 seeds per fruit; $0.63 \%$ of titratable acidity and $11.61^{\circ}$ Brix, resulting in maturity index (SS/TA) of 20 ; and $2.28 \mathrm{~kg}$ of SS per $40.8 \mathrm{~kg}$ box. Despite the large fruits with high number of seeds, 'Piemonte' tangor met the Brazilian standards for mandarin commercialization in the domestic market (CEAGESP, 2011).

Regarding the average fruit production, assessed on the most productive rootstock in 2010-2014 (Table 2), at $6.0 \mathrm{~m} \times 4.0 \mathrm{~m}$ tree spacing, 'Piemonte' tangor yielded $15.9 \mathrm{t} \mathrm{ha}^{-1}$, which is similar to the state of Bahia (15.9 t ha $^{-1}$ ), but significantly lower than the state of São Paulo $\left(31.4 \mathrm{tha}^{-1}\right)$ and the mean Brazilian mandarin productivity in $2015\left(19.4 \mathrm{t} \mathrm{ha}^{-1}\right)$, respectively (IBGE, 2015). On the other hand, the same mean yield increased to $38.6 \mathrm{t} \mathrm{ha}^{-1}$ in 2014, that is, taken the fifth harvest alone (Table 2). Great differences in climate, soil and cultural practices among production regions should be considered for this comparison.

The 'Piemonte' tangor accession evaluated in this work was previously obtained as a nucellar plant from seeds introduced in Brazil from the University of California, Riverside, as a 'Clementine' mandarin $\mathrm{x}$ 'Murcott' tangor hybrid (PASSOS et al., 2007). The similar origin and the general characteristics of the plant and its fruits resemble those of the 'US Furr' mandarin or SRA 337 or C54-4-4 mandarin originally obtained by the USDA (SIEBERT et al., 2010; FURR et al., 2014). 
Table 2. Fruit production of 'Piemonte' tangor [Citrus clementina hort. ex Tanaka x 'Murcott' tangor (C. reticulata Blanco x C. sinensis (L.) Osbeck)] grafted onto 14 rootstocks in rainfed cultivation in Rio Real-BA in the period of 2010-2014 (first to fifth commercial harvests).

\begin{tabular}{|c|c|c|c|c|c|c|c|c|c|c|c|c|}
\hline \multirow{2}{*}{ Rootstock $^{1}$} & \multicolumn{2}{|c|}{ 2010-2014 } & \multicolumn{2}{|l|}{2010} & \multicolumn{2}{|l|}{2011} & \multicolumn{2}{|l|}{2012} & \multicolumn{2}{|l|}{2013} & \multicolumn{2}{|l|}{2014} \\
\hline & & & & & & & & & & & & \\
\hline 'Indio' citrandarin & 167.7 & $\mathrm{a}$ & 28.0 & $\mathrm{a}$ & 46.2 & $\mathrm{a}$ & 29.3 & $\mathrm{~b}$ & 0.8 & $\mathrm{a}$ & 63.4 & $\mathrm{a}$ \\
\hline 'Riverside' citrandarin & 190.6 & $\mathrm{a}$ & 30.0 & $\mathrm{a}$ & 47.2 & $\mathrm{a}$ & 45.9 & $\mathrm{a}$ & 1.9 & $\mathrm{a}$ & 65.6 & $\mathrm{a}$ \\
\hline CLEO x CTCZ - 226 & 27.3 & $\mathrm{c}$ & 3.0 & $\mathrm{c}$ & 11.1 & $\mathrm{c}$ & 4.4 & $\mathrm{c}$ & 0.3 & $\mathrm{a}$ & 8.5 & $\mathrm{~b}$ \\
\hline TSKFL x CTTR - 017 & 38.0 & $\mathrm{c}$ & 6.0 & $\mathrm{c}$ & 12.2 & $\mathrm{c}$ & 7.8 & $\mathrm{c}$ & 1.3 & $\mathrm{a}$ & 10.7 & $\mathrm{~b}$ \\
\hline TSKC x CTSW - 028 & 95.7 & $\mathrm{~b}$ & 14.0 & $\mathrm{~b}$ & 28.4 & $\mathrm{~b}$ & 0.0 & $\mathrm{c}$ & 0.0 & $\mathrm{a}$ & 53.3 & $\mathrm{a}$ \\
\hline TSKFL x CTSW - 049 & 68.7 & $\mathrm{~b}$ & 18.0 & $\mathrm{a}$ & 34.2 & $\mathrm{a}$ & 0.7 & $\mathrm{c}$ & 0.0 & $\mathrm{a}$ & 15.8 & $\mathrm{~b}$ \\
\hline TSKC $\mathrm{x}($ LCR $\mathrm{x}$ TR) -001 & 91.2 & $\mathrm{~b}$ & 14.0 & $\mathrm{~b}$ & 28.1 & $\mathrm{~b}$ & 10.5 & $\mathrm{c}$ & 1.0 & a & 37.6 & $\mathrm{a}$ \\
\hline TSKC x (LCR x TR) - 018 & 89.3 & $\mathrm{~b}$ & 14.0 & $\mathrm{~b}$ & 22.1 & $\mathrm{~b}$ & 9.0 & $\mathrm{c}$ & 0.4 & $\mathrm{a}$ & 43.8 & $\mathrm{a}$ \\
\hline LVK x LVA - 009 & 43.4 & $\mathrm{c}$ & 13.0 & $\mathrm{~b}$ & 13.6 & $\mathrm{c}$ & 2.4 & $\mathrm{c}$ & 2.1 & $\mathrm{a}$ & 12.3 & $\mathrm{~b}$ \\
\hline 'Sunki Tropical' mandarin & 177.0 & $\mathrm{a}$ & 20.0 & $\mathrm{a}$ & 36.9 & $\mathrm{a}$ & 33.7 & a & 2.0 & $\mathrm{a}$ & 84.4 & $\mathrm{a}$ \\
\hline 'Sunki Maravilha' mandarin & 108.7 & $\mathrm{a}$ & 14.0 & $\mathrm{~b}$ & 25.8 & $\mathrm{~b}$ & 17.0 & $\mathrm{~b}$ & 0.0 & $\mathrm{a}$ & 51.9 & $\mathrm{a}$ \\
\hline 'Santa Cruz Rangpur' lime & 190.4 & $\mathrm{a}$ & 30.0 & $\mathrm{a}$ & 46.1 & $\mathrm{a}$ & 19.8 & $\mathrm{~b}$ & 1.9 & a & 92.6 & $\mathrm{a}$ \\
\hline 'Volkamer' lemon & 86.7 & $\mathrm{~b}$ & 9.0 & $\mathrm{~b}$ & 29.2 & $\mathrm{~b}$ & 7.1 & $\mathrm{c}$ & 1.6 & $\mathrm{a}$ & 39.8 & $\mathrm{a}$ \\
\hline 'Cleopatra' mandarin & 139.6 & $\mathrm{a}$ & 15.0 & $\mathrm{~b}$ & 30.8 & $\mathrm{~b}$ & 16.6 & $\mathrm{~b}$ & 2.0 & $\mathrm{a}$ & 75.2 & $\mathrm{a}$ \\
\hline$\overline{C V}(\%)$ & 15.7 & & 22.1 & & 25.4 & & 29.8 & & 37.3 & & 29.6 & \\
\hline
\end{tabular}

(*)Averages followed by the same letter in column belong to the same group by the Scott-Knott test $(P \leq 5 \%)$. ${ }^{1} \mathrm{CLEO}$ ('Cleopatra' mandarin), CTCZ ('Carrizo' citrange), TSKFL ('Sunki da Flórida' mandarin), CTTR ('Troyer' citrange), TSKC (Common 'Sunki' mandarin), CTSW ('Swingle' citrumelo), TR (trifoliate orange), LCR ('Rangpur' lime), LVK ('Volkamer' lemon) and LVA ('Valencia' sweet orange). Respective scientific names are presented in Material and Methods.

Table 3. Weight (W), length (L), diameter (D), peel thickness (P), juice yield (J), number of seeds per fruit (N), titratable acidity (TA), soluble solids content (SS), maturity index (SS/TA) and technology index (TI) of fruits of 'Piemonte' tangor [Citrus clementina hort. ex Tanaka x 'Murcott' tangor (C. reticulata Blanco x C. sinensis (L.) Osbeck)] grafted onto 14 rootstocks in rainfed cultivation in Rio Real-BA at nine years old.

\begin{tabular}{|c|c|c|c|c|c|c|c|c|c|c|c|c|c|c|c|c|c|c|}
\hline Rootstock $^{1}$ & $\begin{array}{l}\text { W } \\
(\mathrm{g})\end{array}$ & & $\begin{array}{c}\mathrm{L} \\
(\mathrm{cm})\end{array}$ & & $\begin{array}{c}\mathrm{D} \\
(\mathrm{cm})\end{array}$ & & $\begin{array}{c}\mathrm{P} \\
(\mathrm{mm})\end{array}$ & & $\begin{array}{c}\mathrm{J} \\
(\%)\end{array}$ & & $\mathrm{N}$ & & $\begin{array}{l}\mathrm{AT} \\
(\%)\end{array}$ & $\begin{array}{c}\text { SS } \\
\left({ }^{\circ} \text { Brix }\right)\end{array}$ & & SS/AT & & $\mathrm{TI}^{2}$ \\
\hline 'Indio' citrandarin & 224 & $\mathrm{a}$ & 6.4 & $\mathrm{a}$ & 7.8 & $\mathrm{a}$ & 2.0 & $\mathrm{a}$ & 52 & $\mathrm{a}$ & 17 & a & 0.72 & 11.5 & $\mathrm{a}$ & 17.3 & $\mathrm{a}$ & $2.47 \mathrm{a}$ \\
\hline 'Riverside' citrandarin & 203 & a & 6.3 & $\mathrm{a}$ & 7.5 & $\mathrm{a}$ & 1.8 & $\mathrm{~b}$ & 48 & $\mathrm{a}$ & 15 & $\mathrm{a}$ & 0.69 & 11.9 & $\mathrm{a}$ & 18.5 & a & $2.37 \mathrm{a}$ \\
\hline CLEO x CTCZ - 226 & 212 & $\mathrm{a}$ & 6.5 & $\mathrm{a}$ & 7.5 & $\mathrm{a}$ & 2.0 & $\mathrm{a}$ & 49 & $\mathrm{a}$ & 14 & $\mathrm{a}$ & 0.57 & 11.6 & $\mathrm{a}$ & 22.4 & $\mathrm{a}$ & $2.34 \mathrm{a}$ \\
\hline TSKFL x CTTR - 017 & 218 & $\mathrm{a}$ & 6.5 & $\mathrm{a}$ & 7.5 & $\mathrm{a}$ & 2.1 & $\mathrm{a}$ & 47 & $\mathrm{a}$ & 13 & $\mathrm{a}$ & 0.63 & 11.7 & $\mathrm{a}$ & 19.5 & $\mathrm{a}$ & $2.26 \mathrm{a}$ \\
\hline TSKC x CTSW - 028 & 205 & $\mathrm{a}$ & 6.3 & $\mathrm{a}$ & 7.5 & a & 1.8 & $\mathrm{~b}$ & 52 & $\mathrm{a}$ & 19 & $\mathrm{a}$ & 0.83 & 11.8 & a & 14.2 & $\mathrm{a}$ & $2.51 \mathrm{a}$ \\
\hline TSKFL x CTSW - 049 & 244 & $\mathrm{a}$ & 6.8 & $\mathrm{a}$ & 8.0 & $\mathrm{a}$ & 2.2 & $\mathrm{a}$ & 48 & $\mathrm{a}$ & 12 & $\mathrm{a}$ & 0.57 & 11.3 & $\mathrm{a}$ & 20.7 & $\mathrm{a}$ & $2.23 \mathrm{a}$ \\
\hline TSKC x (LCR x TR) - 001 & 250 & $\mathrm{a}$ & 6.7 & $\mathrm{a}$ & 7.8 & $\mathrm{a}$ & 2.0 & $\mathrm{a}$ & 44 & $\mathrm{a}$ & 14 & $\mathrm{a}$ & 0.71 & 10.9 & $\mathrm{a}$ & 16.4 & $\mathrm{a}$ & $1.98 \mathrm{~b}$ \\
\hline TSKC x (LCR x TR) - 018 & 230 & a & 6.4 & $\mathrm{a}$ & 7.8 & $\mathrm{a}$ & 2.2 & $\mathrm{a}$ & 50 & $\mathrm{a}$ & 15 & $\mathrm{a}$ & 0.57 & 11.8 & $\mathrm{a}$ & 21.7 & $\mathrm{a}$ & $2.43 \mathrm{a}$ \\
\hline ‘Sunki Tropical' mandarin & 188 & a & 6.1 & $\mathrm{a}$ & 7.3 & $\mathrm{a}$ & 1.6 & $\mathrm{~b}$ & 49 & $\mathrm{a}$ & 18 & $\mathrm{a}$ & 0.70 & 12.5 & a & 20.3 & a & $2.50 \mathrm{a}$ \\
\hline 'Sunki Maravilha' mandarin & 219 & $\mathrm{a}$ & 6.4 & $\mathrm{a}$ & 7.8 & $\mathrm{a}$ & 1.8 & $\mathrm{~b}$ & 50 & $\mathrm{a}$ & 14 & $\mathrm{a}$ & 0.53 & 12.2 & $\mathrm{a}$ & 25.0 & $\mathrm{a}$ & $2.51 \mathrm{a}$ \\
\hline ‘Santa Cruz Rangpur’ lime & 227 & a & 6.4 & $\mathrm{a}$ & 7.9 & $\mathrm{a}$ & 2.0 & $\mathrm{a}$ & 50 & $\mathrm{a}$ & 19 & $\mathrm{a}$ & 0.54 & 11.5 & $\mathrm{a}$ & 22.4 & $\mathrm{a}$ & $2.39 \mathrm{a}$ \\
\hline 'Volkamer' lemon & 227 & $\mathrm{a}$ & 6.5 & $\mathrm{a}$ & 7.9 & $\mathrm{a}$ & 2.5 & $\mathrm{a}$ & 34 & $\mathrm{a}$ & 13 & $\mathrm{a}$ & 0.36 & 10.2 & a & 27.9 & $\mathrm{a}$ & $1.44 \mathrm{~b}$ \\
\hline 'Cleopatra' mandarin & 211 & a & 6.1 & $\mathrm{a}$ & 7.8 & $\mathrm{a}$ & 1.7 & $\mathrm{~b}$ & 46 & $\mathrm{a}$ & 19 & $\mathrm{a}$ & 0.80 & 12.0 & $\mathrm{a}$ & 15.1 & $\mathrm{a}$ & $2.25 \mathrm{a}$ \\
\hline CV $(\%)$ & 10.5 & & 5.0 & & 3.4 & & 12.0 & & 12.3 & & 21.1 & & 29.8 & 6.3 & & 30.5 & & 13.5 \\
\hline
\end{tabular}

(*)Averages followed by the same letter in column belong to the same group by the Scott-Knott test $(P \leq 5 \%) .{ }^{1} \mathrm{CLEO}\left({ }^{\circ} \mathrm{Cleopatra}\right.$ ' mandarin), CTCZ ('Carrizo' citrange), TSKFL ('Sunki da Flórida' mandarin), CTTR ('Troyer' citrange), TSKC (Common 'Sunki' mandarin), CTSW ('Swingle' citrumelo), TR (trifoliate orange), LCR ('Rangpur' lime). Respective scientific names are presented in Material and Methods. ${ }^{2} \mathrm{~kg}$ SS box ${ }^{-1} 40.8 \mathrm{~kg}$ 


\section{Conclusions}

Under the study conditions, 'Riverside' and 'Indio' citrandarins, 'Santa Cruz Rangpur' lime, and 'Cleopatra', 'Sunki Tropical' and 'Sunki Maravilha' mandarins were selected as rootstocks for 'Piemonte' tangor. These rootstocks presented the highest cumulative production associated to large tree size and good fruit quality nine years after planting. Among the new hybrid rootstocks, TSKC x CTSW -028 and TSKC $\mathrm{x}($ LCR $\mathrm{x}$ TR) -018 were the most promising.

\section{Acknowledgements}

To the Coordination for the Improvement of Higher Education Personnel (CAPES), for the Master scholarship for the first two authors; to Fazenda Lagoa do Coco and agronomist Roberto Toyohiro Shibata, for providing the experimental area and technical support; to Embrapa Cassava \& Fruits, for providing plant materials, fruit quality analysis and financial support (MP2 02.13.03.005.00.00); to agronomist Magno Guimarães dos Santos, for technical support.

\section{References}

ALMEIDA C.O; PASSOS O.S.; CUNHA SOBRINHO A.P.; SOARES FILHO W.S. Citricultura brasileira: em busca de novos rumos, desafios e oportunidades na região Nordeste. Cruz das Almas: EMBRAPA Mandioca e Fruticultura, 2011. 160p.

CARVALHO, H.W.L.; MARTINS, C.R.; TEODORO, A.V.; SOARES FILHO, W.S.; PASSOS, O.S. Agronomical performance of 'Piemonte' mandarin grafted on several rootstocks in the Brazilian Coastal Tablelands. Pesquisa Agropecuária Brasileira, Brasília, DF, v.51, n.11, p.1830-1838, 2016.

CEAGESP - Companhia de Entrepostos e Armazéns Gerais de São Paulo. Normas de classificação de citros de mesa. São Paulo: PBMH - Programa Brasileiro para Modernização da Horticultura, 2011. 12p.

CINTRA, F.L.D. Caracterização da região produtora: solo e clima.In: MELO, M.B.; SILVA, L.M.S. (Ed.). Aspectos técnicos dos citros em Sergipe. Aracaju: Embrapa Tabuleiros Costeiros, 2007. p.11-19.

ESPINOZA-NÚÑEZ, E.; MOURÃO FILHO, F.A.A.; STUCHI, E.S. Desenvolvimento vegetativo, produção e qualidade de frutos da tangerina 'Fremont' sobre quatro porta-enxertos. Revista Brasileira de Fruticultura, Jaboticabal, v.29, p.308-312, 2007.
ESPINOZA-NÚÑEZ, E.; MOURÃO FILHO, F.A.A.; STUCHI, E.S.; ORTEGA, E.M.M. Desenvolvimento e produvidade da tangerina "Fairchild" sobre quatro portaenxertos. Ciência Rural, Santa Maria, v.38, p.1553-1557, 2008

FIGUEIREDO, J.O.; NEGRI, J.D.; JÚNIOR, D.M.; PIO, R.M.; AZEVEDO, F.A.; GARCIA, V.X.P. Comportamento de 16 porta-enxertos para o tangor Murcott na região de Itirapina-SP. Revista Brasileira de Fruticultura, Jaboticabal, v.28, n.1, p.76-78, 2006.

FRANÇA, N.O.; AMORIM, M.S.; GIRARDI, E.A.; PASSOS, O.S.; SOARES FILHO, W.S. Performance of 'Tuxpan Valencia' sweet orange grafted onto 14 rootstocks in northern Bahia, Brazil. Revista Brasileira de Fruticultura, Jaboticabal, v.38, n.4, e-684, 2016.

FURR, J.; REECE, P.; KAHN, T.; SIEBERT, T.; BARRY, G.; MCCOLLUM, G.; CASTLE, W.; STOVER, E.'US Furr' and 'US Furr-ST' mandarins. Journal of the American Pomological Society, Pennsylvania, v.68, n.4, p.198-203, 2014.

IBGE. IBGE estados Bahia lavoura permanente 2015. Rio de Janeiro, 2015. Disponível em: <http://www.ibge. gov.br/estadosat/temas.php?sigla=ba\&tema=lavouraperm anente2015>. Acesso em: 07 maio 2017.

JOMORI, M.L.L.; SASAKI, F.F.C.; BERNO, N.D.; GIMENES, L.C.; KLUGE, R.A. Desverdecimento e armazenamento refrigerado de tangor 'Murcott' em função de concentração e tempo de exposição ao etileno. Semina: Ciências Agrárias, Londrina, v.35, n.2, p.825834, 2014.

LEDO, A.S.; OLIVEIRA, T.K.; RITZINGER, R.; AZEVEDO, F.F. Produção de limas ácidas, tangerineira e híbridos sobre diferentes porta-enxertos no Estado do Acre. Revista Ciência Agronômica, Fortaleza, v.39, n.2, p.263-268, 2008.

MARTINS, C.R.; CARVALHO, H.W.L.; TEODORO,A.V.; SOARES FILHO, W.S.; PASSOS, O.S.; CARVALHO, L.M .Cultivares de laranjeiras, limeiras ácidas e tangerineiras para a diversificação do cultivo em áreas de Tabuleiros Costeiros do Estado de Sergipe. Aracaju: Embrapa Tabuleiros Costeiros, 2015. 10p. (Comunicado Técnico 162).

MARTINS, C.R.; CARVALHO, H.W.L.; TEODORO, A.V.; SOARES FILHO, W.S.; PASSOS, O.S. Agronomical performance of citrus scion cultivars grafted on Rangpur lime in north-eastern Brazil. Australian Journal of Crop Science, Sydney, v.10, n.1, p.16-23, 2016. 
MOURÃO FILHO, F.A.A.; NÚÑEZ, E.E.; STUCHI, E.S.; ORTEGA, E.M.M. Plant growth, yield, and fruit quality of Fallglo and Sunburst mandarins on four rootstocks. Scientia Horticulturae, Amsterdam, v.114, p.45-49, 2007.

PACHECO, C.A.; MARTELLI, I.B.; POLYDORO, D.A.; SCHINOR, E.H.; PIO, R.M.; KUPPER, K.C.; AZEVEDO, F.A. Resistance and susceptibility of mandarins and their hybrids to Alternaria alternata. Scientia Agricola, Piracicaba, v.69, n.6, p.386-392, 2012.

PASSOS, O.S.; SOARES FILHO, W.S.; CUNHA SOBRINHO, A.P.; SOUZA, A.S.; SANTOS, L.C.; PEIXOUTO, L.S. Banco ativo de germoplasma de citros da embrapa mandioca e fruticultura tropical: passado, presente e futuro. Cruz das Almas: Embrapa Mandioca e Fruticultura, 2007. 61p. (Documentos, 163).

PEREIRA, M.E.C.; CANTILLANO, F.F., GUTIEREZ, A.S.D.; ALMEIDA, G.V.B. Procedimentos pós-colheita na produção integrada de citros. Cruz das Almas: Embrapa Mandioca e Fruticultura Tropical, 40p. 2006. (Documentos, 156).

POMPEU JUNIOR, J. Porta-enxertos. In: MATTOS JUNIOR, D.; PIO, R.M.; DE NEGRI, J.D.; POMPEU JUNIOR, J. (Ed.). Citros. Campinas: Instituto Agronômico de Campinas: Fundag, 2005. p.63-104.

RAMOS, Y.C.; STUCHI, E.S.; GIRARDI, E.A.; LEAO, H.C.; GESTEIRA, A.S.; PASSOS, O.S.; SOARES FILHO, W.S. Dwarfig rootstocks for Valencia sweet orange. Acta Horticulturae, Leuven, v.1065, p.351-354, 2015.
REUTHER, W. Climate and citrus behavior. IN: REUTHER, W. (Ed). The citrus industry. Riverside: University of California, 1973. v.3, p.280-337.

SANTANA-VIEIRA, D.D.S.; FRESCHI, L.; ALMEIDA, L.A.H.; MORAES, D.H.S.; NEVES, D.M.; SANTOS, L.M.; BERTOLDE, F.Z.; SOARES FILHO, W.S.; COELHO FILHO, M.A.; GESTEIRA, A.S. Survival strategies of citrus rootstocks subjected to drought. Scientific Reports, London, v.6, e-38775, 2016.

SIEBERT, T.; KRUEGER, R.; KAHN, T.; BASH, J.; VIDALAKIS, G. Descriptions of new varieties recently distributed from the Citrus Clonal Protection Program. Citrograph, Visalia, v.1, n.2, p.20-26, 2010.

SILVA, S.R.; STUCHI, E.S.; GIRARDI, E.A.; AVILÉS, T.C.; BASSAN, M.M. Desempenho da tangerineira 'Span Americana' em diferentes porta-enxertos. Revista Brasileira de Fruticultura, Jaboticabal, v.35, n.4, p.10521058, 2013.

STUCHI, E.S.; NÚÑEZ-ESPINOZA, E.; MOURÃO FILHO, F.A.A.; ORTEGA, E.M.M. Vigor, produtividade e qualidade de frutos de quatro tangerineiras e híbridos sobre quatro porta-enxertos. Revista Brasileira de Fruticultura, Jaboticabal, v.30, p.741-747, 2008. 